\title{
THE EFFECT OF USING ROAD SAFETY EQUIPMENT AND SYSTEMS AND DETERMINE THEIR ROLE ON THE SUBURBAN ROADS' SAFETY PERFORMANCE
}

\author{
G. Ghaffari ${ }^{1, *}$ and H. Zoghi ${ }^{2}$ \\ ${ }^{1}$ Islamic Azad University, Ayatollah Amoli, Civil Engineering Department of Transportation, \\ Amol, Iran \\ ${ }^{2}$ Faculty of Engineering, Islamic Azad University of Karaj, Iran
}

Published online: 15 May 2016

\begin{abstract}
In the present communities transportation is a critical component of human life, and one of the main categories in the specification transportation system is the subject of safety. Considering the number of road accidents and deaths caused by it, unfortunately Iran is at the top of countries with the highest number of deaths in traffic accidents, therefore, this has led to that causes of accidents be investigated. To achieve high safety many factors are involve, including appropriate geometric conditions, warning signs and marks, inhibiting rules, safer vehicles, driver familiar with the rules. In this paper, we investigate and evaluate each safety equipment on road performance and with case study on the Tehran-Firouzkouh road determine the existing traffic control equipment situation and by multi-criteria weighting systems AHP decision-making models has been set to evaluate the effects of these factors on safety function. Then according to existing road conditions and the contribution of roads' different sectors of these systems, a safety priority index number is defined between 0 and 100 and prioritize different levels were expressed in terms of risk.
\end{abstract}

Author Correspondence, e-mail: authorC@gmail.com

doi: http://dx.doi.org/10.4314/jfas.v8i3s.252

Journal of Fundamental and Applied Sciences is licensed under a Creative Commons Attribution-NonCommercial 4.0 International License. Libraries Resource Directory. We are listed under Research Associations category. 
The results have shown that indices median, lighting and panel type and the road's longitudinal underlining have been identified to have the highest impact on safety. This issue considering sections with complex geometric design with plenty of horizontal curves are very important; also transverse road underlining and warning and regulatory signs in the road have the high weight. But what is noteworthy in this regard is that the total weight of road horizontal symptoms include (underlining and text lines and bumps) is obtained 0.306, and the total weight of the vertical signs (regulatory and warning signs, and traffic lights) 0.181 . This issue shows that importance and the effect of horizontal systems on roads is far more than vertical signs of road's margins.

Keywords: Safety; safety equipment and systems; hierarchical analysis.

\section{INTRODUCTION}

Assessment of safety status quantitatively beside effective parameters such as design, implementation and adoption with environment in process management and project development has always been a challenging issue. However, the issue of safety is considered as an integral part of design policies based on desired uses. Although the geometric correction by itself can be very effective in quantitative reducing road accidents statistics, but reducing the severity of accidents, mostly will be possible by safety control rules. Unfortunately, nowadays there are many inhomogeneity on country roads and their physical and geometric margins that this caused a crisis in the severity of accidents in these areas. A safe road is a range without any objects and dangerous places and also requires the existence of safety equipment at the margins. For designing a road and its appurtenances, designers should use the geometric criteria, take into account all circumstances, reduce and evaluate the influence of possible outside of the road factors on the road safety. So the safety of the road network in a general classification requires attention to three major factors geometric design, maintenance and traffic control signs (Figure $1)$. 


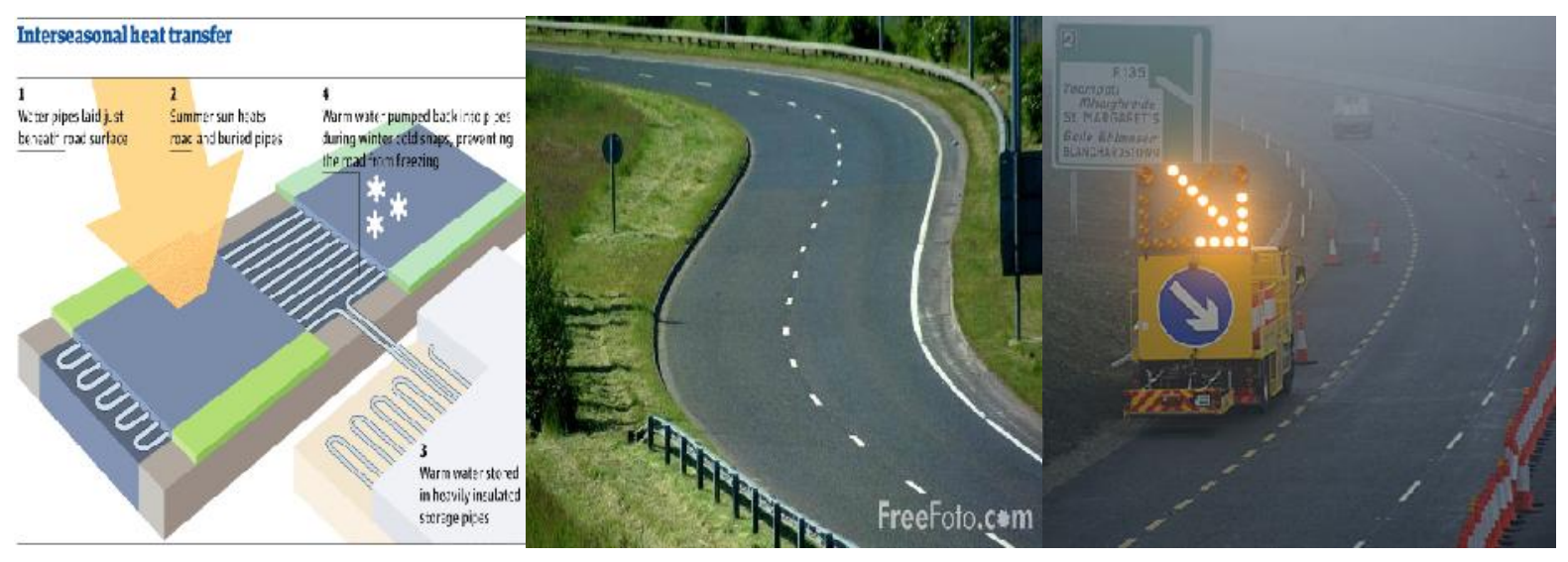

Fig.1. The road factor is one of the accident factors

Road factor consists of different factors that road and its margin are the most important. A number of other parameters that are considered as road factor are as following:

- Width and geometry of the road

- Lightening situation

- Natural obstacles which prevent adequate vision such as tree

- Lack of good protection on roadside

- Road signs and other control measures including horizontal and vertical signs

- Resorts and parking situation

- Rainy weather or fog

- Road surface condition in terms of drainage and superstructure

Horizontal and vertical signs, road safety equipment, control equipment, smart traffic and road safety equipment and all supply of road safety are used in order to regular and predictable traffic movement and thereby provide road safety, this aim is supplied with listed equipment and reduces accidents and increase safety. Therefore, in this thesis we will evaluate the performance of any of the safety equipment, and statistical modeling techniques will be used. Due to many losses of life and property that road accidents impose on human societies, considering the issue of safety as the first priority in transportation and land use management plans, is reasonable and acceptable. Prerequisite principles of sustainable development in road safety is providing a longterm or medium-term national-scale safety plan. In this regard, most recently in developed countries an issue is emerged called safety engineering which its aim is improving engineering 
design principles to enhance the level of road safety. The most effective step towards understanding the factors involved in road safety, e.g. the vehicle, humane, environment and the complex interaction of these factors, is conduct in-depth studies about problem-solving. Unfortunately, in developing countries information relating to these factors is rarely available or information and statistics often are not reliable, and are collected by different institutions to satisfy the periodic needs. Integrating this information is also time-consuming and sometimes impossible. In addition to the aforementioned problems in many developing countries, rapid growth in number of motor vehicles is also seen. Nowadays, the issue of security supply in transportation is one of the basics of traffic engineering, traffic and transportation planning. Each year, more than 1.17 million people die in road accidents, $70 \%$ of which is related to developing countries, and more than 10 million people are disabled and wounded. It is expected that in the next 10 years in developing countries, 6 million people will die and 60 million people will be injured, unless appropriate measures are taken to prevent it. The World Health Organization (WHO) show that in 1990, traffic accidents were in ninth grade on the list of the most important health problems and is predicted that until 2020 road accidents will be the third most important cause of death and disability in human societies. The harsh reality raised in the organization report imply that $50 \%$ of those killed are 15 to 44 years old and economically are considered as most influential persons in society. In general, road accidents approximately waste 1 to 3 percent of Gross National Products (GNP) that is very significant figure. No doubt these costs and damages are a huge obstacle in the way of economic and social development of developing countries.

\section{RESEARCH BACKGROUND}

One of the most important parameters assessed in most countries of the world, the international community and the United Nations is traffic safety. By study of traffic accidents we can identify factors in the occurrence of traffic accidents and by defining and describing factors in accidents we can improve transportation system. So that by decreasing and minimize the causes of the accident create a safer transportations system. Also, studies in the field of road accidents and fatalities in the worldwide suggests that road accidents even in developed and industrial countries is also top causes of death. Also, studies of World Health Organization show that in 2020 road accidents will be one of the three main causes of death in the world. Road safety experts divided 
effective factors in traffic accidents and injuries and deaths into four categories. The first factor is human and human errors which have most important roles in accidents. The second factor is the vehicle that each of these factors include detailed parameters. The third road environment factor and fourth factor is discussion about road safety management, which in recent years has been paying special attention to this fact. Figure 2 which is prepared by Piyark World Assembly and is published in road safety handbook by the same Assembly, can be considered as the result of one of most timely global analysis of three factors people, roads and vehicles, the contribution of each factor in absolute or in combination with other agents are shown by three circles.

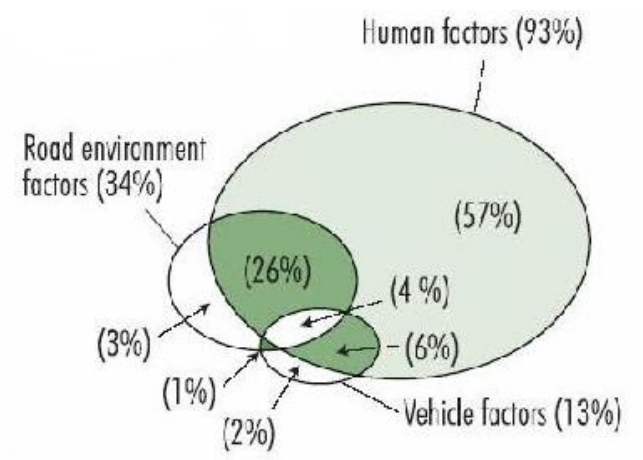

Fig.2. The curve of three factors in accidents

Assessment of safety status quantitatively beside effective parameters such as the design, implementation and adoption with environment in management process and project development has always been a challenging issue. However, the issue of safety is considered as an integral part of policy design based on user type. Although the geometric correction alone can be very effective in quantitatively reducing road accidents statistics, but reducing the severity of accidents, mostly will be possible by control safety principles in action. Nowadays, in the design of several tools quantitative assessment of both administrative convenience and compatibility with the environment plan is available. But the tools currently used for quantitative assessment of safety in the design are relatively new. Organizations related to safety issues in country should use them in the various project phases by increasing knowledge and information in connection with these tools and standards. Quantitative evaluation of safety, enables client and design consultant better understand the role of safety in the design process, and consider these factors, along with other factors in the design process of the project. Due to the high rate of road casualties in Europe (43,000 annually), RISER research project started at 2003 and lasted for 36 
months to evaluate the severity of accidents. The CMF indicator-based projects showed that although only $10 \%$ of all accidents in Europe is related to ROR crashes, but this relatively low rate, approximately included $45 \%$ of deaths statistics. CMF is one of the tools that today's road transport organizations in the developed countries including the FHWA in U.S.A use it in order to increase safety in the different before and after phases of the design. Also original standard application that covers design and traffic control equipment locating, is Manual on Uniform Traffic Control Device (MUTCD). Federal roads Office is national publisher of MUTCD, which is considered as a minimum standard and is considered as a model for other instructions that are provided at different state levels. One of the major goals of MUTCD guidelines is integration and homogeneity in using, locating and designing traffic control equipment. MUTCD guidelines state that a purpose of traffic control equipment is improve road safety by establishing a regular movement of all users on the streets and roads. In addition, for carrying out this mission more effectively the guide has introduced five characteristics of effective traffic control equipment features.

\section{RESEARCH METHODOLOGY}

Therefore, we can outline the available traffic equipment and systems on the road as factors affecting safety and performance. Therefore, in this study by conducting a case study on the Tehran-Firouzkouh Road which includes three main parts Tehran-Boomehen, BoomehenDamavand, Damavand- Firoozkooh, we identify the status of equipment and organization of road safety and traffic control systems and through multi-criteria weighting system through AHP decision-making models the impact of these factors on immune function has been investigated. According to existing road status and the contribution of different sectors of roads from these systems, a number defined as safety priority index and different levels were expressed in terms of risk. MADM models are used to select the most appropriate option from the m option. Hwang \& Yoon defined multi-criteria decision making as: "Multi-criteria decision making refers to preferential decisions (eg, evaluation, prioritization and selection) from among the categorized options by multiple indexes (and often conflicting)". As mentioned above, MCDM models are used to select the most appropriate choice among the possible options. These models are usually formulated by decision matrix. Analytic Hierarchy Process is one of the most comprehensive systems which is designed for multiple attribute decision making which is accordance to a strong 
theory based on axioms and has been built according to a paired comparison. Since in these methods all parameters have not been compared at once and criteria are compared in pairs, so weighting perform more accurately. This process in involved different options in decision making and provide sensitivity possibility on criteria and sub criteria. Analytical Hierarchy Process (AHP), which was presented by the Saaty (Saaty 1980) has been used in various place projects (Ying et al. 2007). Due to the uncertainty in describing and ranking criteria, we need a way to model uncertainty.

\section{DATA ANALYSIS AND CASE STUDY}

Tehran-Firouzkouh is considered as one of the main artery between Tehran and North of Iran. In addition to traffic of Pardis, Roodehen, Boomehen, Damavand and other relevant sectors, it also suffers inter-provincial traffic between Tehran and north of Iran. Therefore, it is considered as one of busy roads of the province with indicator of policymaking and importance. This road has three main sections in accordance with Table 1.

Table 1. Studying parts of Tehran-Firouzkouh highway

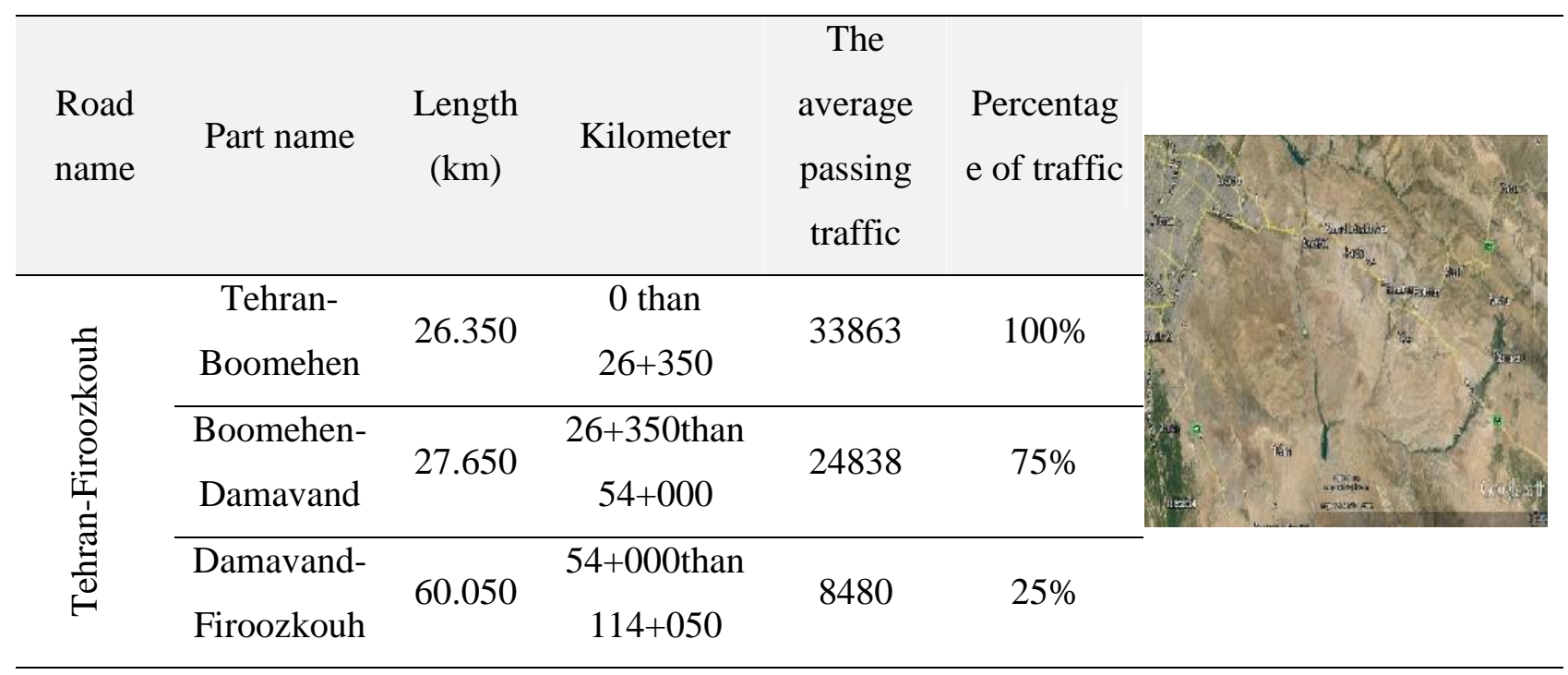

It is necessary to say that the data such as geometry and the type and number of equipment and systems for ensuring safety in the highway is taken from Roads and Urban Development Office of Tehran Province which includes survey-based maps with proper placement signs and symptoms on it. In Figure 3 how to choose data by available maps is displayed. 


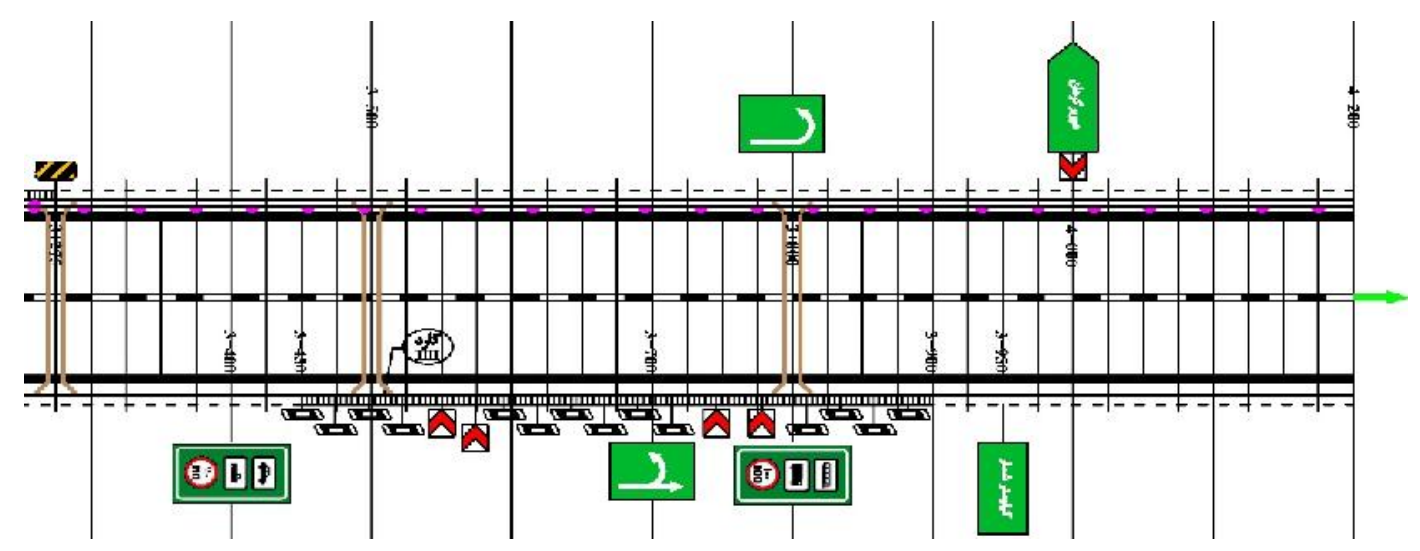

Fig.3. How to choose the necessary data by AutoCAD maps

After carried out reviews and gather information about the impact of systems and traffic control equipment on road safety performance and using collected data in accordance with Table 2, the weighting of each of the index will be discussed by AHP method. Considered equipment and indexes of road existing systems and equipment have been shown in Table 2.

Table 2. The data collection based on 12 indicators of existing equipment and systems

\begin{tabular}{ccccc}
\hline Roa & R & Sta & En & Leng \\
$\mathrm{d}$ & $\mathrm{o}$ & rtin & din & th of \\
nam & ut & $\mathrm{g}$ & $\mathrm{g}$ & secti \\
$\mathrm{e}$ & $\mathrm{e}$ & kilo & kilo & on \\
& & met & met & \\
& & er & er & \\
& & & &
\end{tabular}

Safety equipment and systems

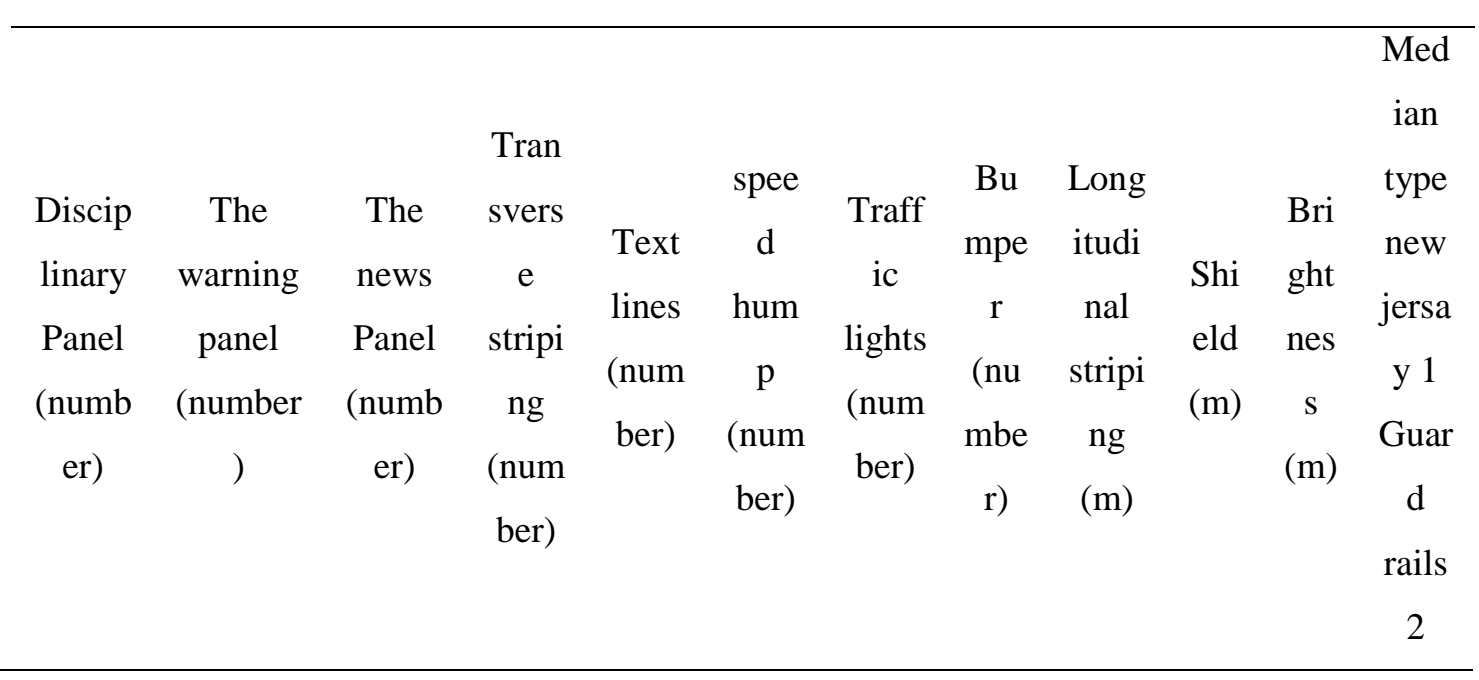




\begin{tabular}{|c|c|c|c|c|c|c|c|c|c|c|c|c|c|c|c|c|}
\hline \multirow{3}{*}{$\begin{array}{l}\text { Tehr } \\
\text { an- } \\
\text { Boo } \\
\text { meh } \\
\text { en }\end{array}$} & $\begin{array}{l}\mathrm{G} \\
\mathrm{o}\end{array}$ & 0 & $\begin{array}{l}26+ \\
350\end{array}$ & $\begin{array}{c}26.3 \\
50\end{array}$ & 27 & 1.080 & 24 & 2 & 0 & 0 & 5 & 8 & $\begin{array}{r}297 . \\
332\end{array}$ & $\begin{array}{l}40 . \\
424\end{array}$ & $\begin{array}{l}10 . \\
16\end{array}$ & $1 \& 2$ \\
\hline & $\begin{array}{l}\mathrm{re} \\
\mathrm{tu} \\
\mathrm{rn}\end{array}$ & 0 & $\begin{array}{l}26+ \\
350\end{array}$ & $\begin{array}{c}26.3 \\
50\end{array}$ & 23 & 1.115 & 23 & 10 & 0 & 0 & 5 & 9 & $\begin{array}{l}151 . \\
203\end{array}$ & $\begin{array}{l}35 . \\
841\end{array}$ & & \\
\hline & $\begin{array}{l}\text { to } \\
\text { ta } \\
1\end{array}$ & 0 & $\begin{array}{l}26+ \\
350\end{array}$ & $\begin{array}{c}26.3 \\
50\end{array}$ & 50 & 2.195 & 47 & 12 & 0 & 0 & 10 & 17 & $\begin{array}{r}448 . \\
535\end{array}$ & $\begin{array}{l}76 . \\
265\end{array}$ & $\begin{array}{l}10 . \\
016\end{array}$ & $1 \& 2$ \\
\hline \multicolumn{4}{|c|}{$\begin{array}{c}\text { Toward way length } \\
\text { per meter }\end{array}$} & $\begin{array}{c}26.3 \\
50\end{array}$ & 0.0009 & 0.0417 & 0.0009 & $\begin{array}{c}0.00 \\
02\end{array}$ & $\begin{array}{c}0.00 \\
00\end{array}$ & $\begin{array}{c}0.00 \\
00\end{array}$ & $\begin{array}{c}0.00 \\
02\end{array}$ & $\begin{array}{c}0.00 \\
03\end{array}$ & $\begin{array}{c}8.51 \\
11\end{array}$ & $\begin{array}{l}1.4 \\
472\end{array}$ & $\begin{array}{l}0.1 \\
901\end{array}$ & \\
\hline \multirow{3}{*}{$\begin{array}{c}\text { Boo } \\
\text { meh } \\
\text { en- } \\
\text { Firo } \\
\text { ozko } \\
\text { uh }\end{array}$} & $\begin{array}{l}\mathrm{G} \\
\mathrm{o}\end{array}$ & $\begin{array}{r}26 \\
+3 \\
50\end{array}$ & $\begin{array}{c}114 \\
+0 . \\
050\end{array}$ & $\begin{array}{c}87.7 \\
00\end{array}$ & 84 & 2.610 & 165 & 127 & 40 & 16 & 37 & 23 & $\begin{array}{l}308 . \\
797\end{array}$ & $\begin{array}{l}61 . \\
583\end{array}$ & $\begin{array}{l}10 . \\
880\end{array}$ & $2 \& 3$ \\
\hline & $\begin{array}{l}\mathrm{R} \\
\text { et } \\
\text { ur } \\
\mathrm{n}\end{array}$ & $\begin{array}{r}26 \\
+3 \\
50\end{array}$ & $\begin{array}{c}114 \\
+0 . \\
050\end{array}$ & $\begin{array}{c}87.7 \\
00\end{array}$ & 102 & 1.797 & 113 & 47 & 19 & 6 & 28 & 26 & $\begin{array}{l}269 . \\
295\end{array}$ & $\begin{array}{l}41 . \\
771\end{array}$ & $\begin{array}{l}21 . \\
612\end{array}$ & \\
\hline & $\begin{array}{l}\mathrm{T} \\
\text { ot } \\
\text { al }\end{array}$ & $\begin{array}{r}26 \\
+3 \\
50\end{array}$ & $\begin{array}{c}114 \\
+0 . \\
050\end{array}$ & $\begin{array}{c}87.7 \\
00\end{array}$ & 186 & 4.407 & 278 & 174 & 59 & 22 & 65 & 49 & $\begin{array}{l}605 . \\
092\end{array}$ & $\begin{array}{c}103 \\
.35 \\
4\end{array}$ & $\begin{array}{l}32 . \\
492\end{array}$ & $2 \& 3$ \\
\hline \multicolumn{4}{|c|}{$\begin{array}{l}\text { Toward the way } \\
\text { length per meter }\end{array}$} & $\begin{array}{c}87.7 \\
00\end{array}$ & 0.0011 & 0.0251 & 0.0016 & $\begin{array}{c}0.00 \\
10\end{array}$ & $\begin{array}{c}0.00 \\
03\end{array}$ & $\begin{array}{c}0.00 \\
01\end{array}$ & $\begin{array}{c}0.00 \\
04\end{array}$ & $\begin{array}{c}0.00 \\
03\end{array}$ & $\begin{array}{c}3.44 \\
98\end{array}$ & $\begin{array}{l}0.5 \\
892\end{array}$ & $\begin{array}{l}0.1 \\
852\end{array}$ & \\
\hline
\end{tabular}

Then, by help of Analytical Hierarchy Process (AHP) weighting of each of the 12 indicators shown in the table above will be discussed in order to amount and the present status of systems and traffic control equipment. Then, road safety priority number is given according to the weight of each indicator and the share of each indicator than the length of the piece. Therefore, to form the comparison matrix experts' opinions were used and the most important criteria in relation to one another according to experts is determined orally and then use the Table 3, expert opinion 
will be replaced with numeric scale. In this study population included 40 safety experts of General Directorate of Roads and Urban Development of Tehran Province, Firoozkooh, Boomehen and Roodehen.

Table 3. The value of the most important criteria than one another according to AHP method

\begin{tabular}{ccc}
\hline \multicolumn{2}{c}{ Preferences } & $\begin{array}{c}\text { Numerical } \\
\text { amount }\end{array}$ \\
\hline $\begin{array}{c}\text { quite important or very } \\
\text { preferable }\end{array}$ & 9 \\
\hline $\begin{array}{c}\text { Preferences or strong } \\
\text { desirability }\end{array}$ & $\begin{array}{c}\text { (Very Strongly } \\
\text { Perfected) }\end{array}$ & 7 \\
\hline $\begin{array}{c}\text { Preferences or strong } \\
\text { desirability }\end{array}$ & (Strongly Perfected) & 5 \\
\hline preferred or better & (Moderately Perfected) & 3 \\
\hline $\begin{array}{c}\text { Preferences or importance or } \\
\text { the same desirability }\end{array}$ & (Equally Perfected) & 1 \\
\hline $\begin{array}{c}\text { Preferences among those } \\
\text { period }\end{array}$ & & $8,6,4,2$ \\
\hline
\end{tabular}

It is obvious that despite the 12 criteria, we will have $12 \times 12$ matrix, 4 main diagonal of this matrix because of the same preference than itself was one, that if a ij is one of its elements it will indicate that how a i will be superior and more important than a $\mathrm{j}$.

Table 4. Comparison criteria matrix in AHP method

\begin{tabular}{cccccccccccccc}
\hline & $\begin{array}{c}\text { Median } \\
\text { type }\end{array}$ & Brightness & Shield & $\begin{array}{c}\text { Longitudinal } \\
\text { striping }\end{array}$ & Buffer & $\begin{array}{c}\text { traffic } \\
\text { light }\end{array}$ & $\begin{array}{c}\text { Speed } \\
\text { Hump }\end{array}$ & Script & $\begin{array}{c}\text { Transverse } \\
\text { striping }\end{array}$ & $\begin{array}{c}\text { News } \\
\text { panel }\end{array}$ & $\begin{array}{c}\text { Warning } \\
\text { panel }\end{array}$ & $\begin{array}{c}\text { Disciplinary } \\
\text { Panel }\end{array}$ \\
\hline Median type & 1 & 0.11 & 0.14 & 0.20 & 0.14 & 0.50 & 0.25 & 0.17 & 0.17 & 0.50 & 0.33 \\
\hline Brightness & 9.1 & 1 & 0.13 & 0.17 & 0.50 & 0.25 & 0.33 & 0.25 & 0.20 & 0.25 & 0.50 & 0.20 \\
\hline Shield & 7.3 & 8.07 & 1 & 0.25 & 0.20 & 0.33 & 0.50 & 0.50 & 0.25 & 0.50 & 0.50 & 0.20 \\
\end{tabular}


G. Ghaffari et al.

\begin{tabular}{|c|c|c|c|c|c|c|c|c|c|c|c|c|}
\hline $\begin{array}{l}\text { Longitudinal } \\
\text { striping }\end{array}$ & 4.9 & 6.10 & 4.00 & 1 & 0.33 & 0.50 & 0.20 & 0.50 & 0.25 & 0.50 & 0.50 & 0.50 \\
\hline Buffer & 7.1 & 1.96 & 5.45 & 3.12 & 1 & 0.50 & 0.50 & 0.50 & 0.33 & 0.50 & 0.50 & 0.33 \\
\hline traffic light & 1.95 & 3.89 & 3.23 & 2.07 & 1.96 & 1 & 0.25 & 0.17 & 0.17 & 0.33 & 0.33 & 0.20 \\
\hline $\begin{array}{l}\text { Speed } \\
\text { Hump }\end{array}$ & 3.86 & 3.11 & 2.2 & 5.08 & 1.89 & 4.15 & 1 & 0.25 & 0.20 & 0.50 & 0.33 & 0.25 \\
\hline Script & 6.2 & 4.13 & 1.8 & 2.11 & 2.02 & 6.46 & 4.12 & 1 & 0.17 & 0.33 & 0.25 & 0.33 \\
\hline $\begin{array}{l}\text { Transverse } \\
\text { striping }\end{array}$ & 6.0 & 5.06 & 3.89 & 4.14 & 2.91 & 4.15 & 5.09 & 5.90 & 1 & 0.50 & 0.50 & 0.50 \\
\hline News panel & 2.33 & 4.11 & 1.89 & 2.09 & 1.88 & 2.89 & 1.94 & 2.91 & 2.09 & 1 & 0.17 & 0.11 \\
\hline $\begin{array}{c}\text { Warning } \\
\text { panel }\end{array}$ & 3.12 & 1.98 & 1.93 & 2.11 & 2.23 & 2.80 & 3.12 & 4.07 & 2.23 & 6.04 & 1 & 0.14 \\
\hline $\begin{array}{c}\text { Disciplinary } \\
\text { Panel }\end{array}$ & 3.06 & 4.87 & 5.03 & 3.14 & 3.04 & 5.11 & 4.33 & 3.23 & 1.86 & 8.94 & 7.26 & 1 \\
\hline
\end{tabular}

Then, using pairwise comparison matrix for each criterion by geometric mean method, the weight of each criterion was calculated in AHP method. Following formula is used for using the geometric mean method to calculate the weight of each criterion.

$$
w_{i}=\left(\prod_{1}^{n} a_{i j}\right)^{1 / n}
$$$$
w_{i}^{\prime}=\frac{w_{i}}{\sum_{1}^{n} w_{i}}
$$

Where $w_{i}$ is the relative weight of $\mathrm{i}$ criteria and $a_{i j}$ is the matrix AHP component of row $\mathrm{i}$, column $\mathrm{j}$ and $\mathrm{n}$ is the number of criteria and for normalization of achieved weight $w_{i}^{\prime}$ is 
calculated. Notable point after the formation of matrix comparisons is calculation of incompatibility ratio which is calculated using the following equation.

$C I=\frac{\lambda_{\max }-n}{n-1}=\frac{1}{n(n-1)} \sum_{1 \leq i \leq j \leq n}\left(\varepsilon_{i j}+\varepsilon_{j i}-2\right)$

$C R=\frac{C I}{R I}$

In the following equation $\lambda_{\max }$ is the highest amount of Eigen value in comparing matrix and CI is compatible index and is related to $E=\left(\varepsilon_{i j}\right)$ turmoil matrix. RI is a random index, which is calculated using the AHP method provided values, CR also is compatible ratio and if CR amount will be less than 0.1 raised comparisons by experts are compatible with each other and otherwise comparisons must be repeated. As a result n numbers are obtained as normalized weight of each criterion (Table 5).

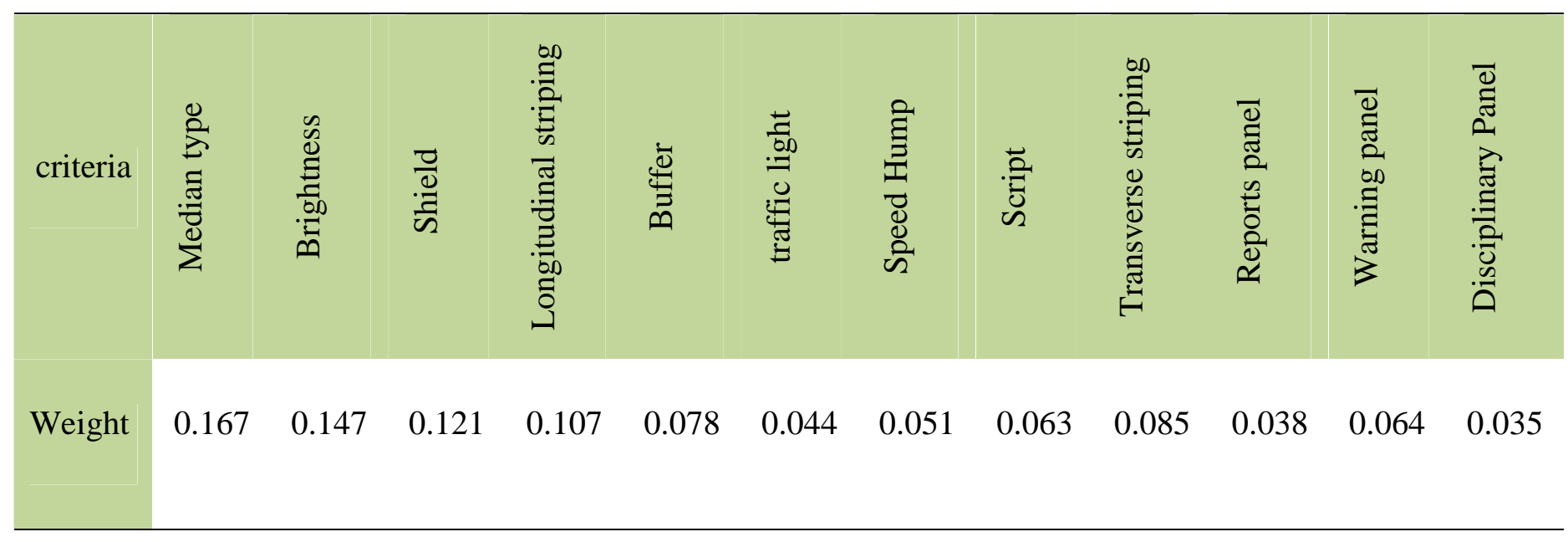




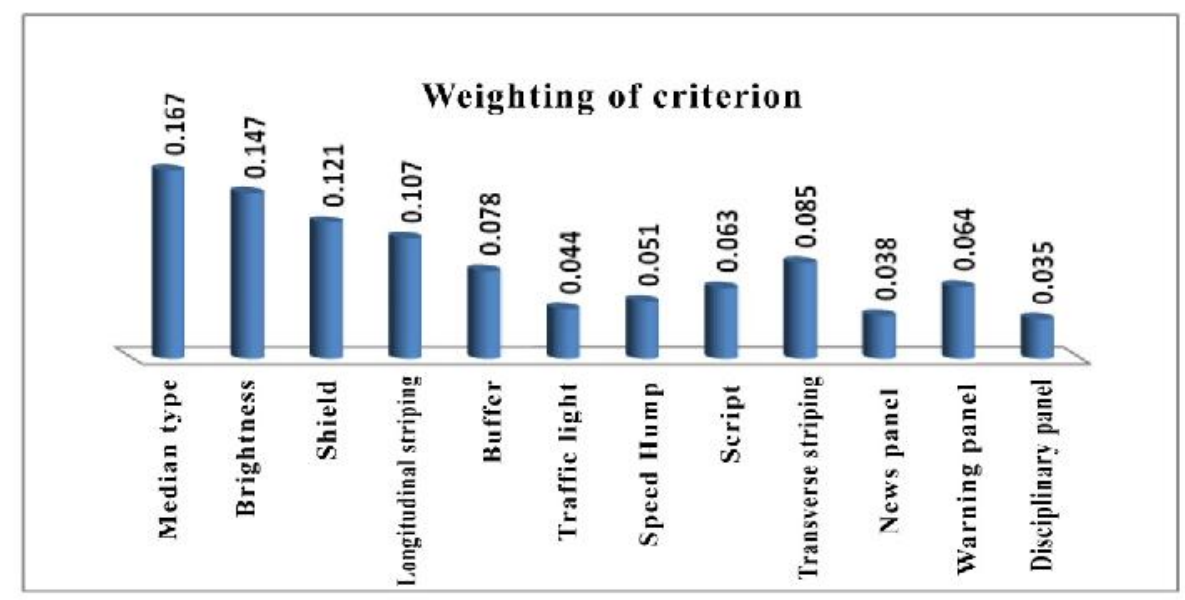

Fig.4. Road's each general indicators weights chart

As the table and chart related to the general indices of roads is shown, kind of a median, brightness and shields and longitudinal striping have been identified to have the highest impact on safety. This issue is more important according to sections with complex geometric design with horizontal curves. Also transverse striping, warning and disciplinary signs in the road have high weight. But what is striking in this way is the point that weight of horizontal marks (striping and text lines and Speed Hump) equals 0.306, and the total weight of the vertical mark (regulatory and warning signs, traffic lights) equals 0.181 . This issue shows the importance and the effect of horizontal systems on roads more than marginal vertical signs. After determining the weight of each of the general indices related to equipment and security system in the road, risk index were calculated as the table below. The method of calculation is in this way that according to the share of each section of road signs and traffic facilities in the fourth quarter of this research is obtained by multiplying the weight of each criterion and finally, the risk taking of road has been introduced as number between 0 and 100, and as a percentage of a safe level. After accounting risk taking indicator of a cross section of road, we determine the priority of safety actions at that time. But according to the point that Tehran-Firouzkouh highway has different sections dealing with residential and marginal areas, and the amount of pedestrian movement in this road is high, and accident statistics indicate that the axis of pedestrian accidents have a significant contribution, therefore, this criterion is considered as a separate criterion and according to the 
accidents occurred at different times in the way. Therefore according to these two factors and the amount of movement in roads safety measures priority were numbered in order from 1 to 4.

- Priority 1: high general risk index and high risk of pedestrian

- Priority 2: above average general risk index and above average pedestrian's risk

- Priority 3: above average general risk index, and low risk of pedestrians

- Priority 4: low general risk index and low risk of pedestrian

Part of sub-sections risk taking calculation index categories in the case study is displayed in Table 6.

Table 6. Calculation of the sub-sections risk taking index in case study

\begin{tabular}{|c|c|c|c|c|c|c|c|}
\hline $\begin{array}{l}\text { Priority } \\
\text { number }\end{array}$ & $\begin{array}{c}\text { Risk } \\
\text { taking } \\
\text { amount of } \\
\text { road }\end{array}$ & $\begin{array}{l}\text { The risk } \\
\text { amount of } \\
\text { pedestrian }\end{array}$ & $\begin{array}{l}\text { The } \\
\text { average } \\
\text { speed of } \\
\text { movement }\end{array}$ & $\begin{array}{c}\text { Amount of } \\
\text { passing } \\
\text { traffic }\end{array}$ & Length km & End km & Start Km \\
\hline 4 & 33 & 30 & \multirow{10}{*}{70} & \multirow{10}{*}{36.472} & 2.600 & 3.600 & 0 \\
\hline 3 & 56 & 30 & & & 1.100 & 3.700 & 2.600 \\
\hline 4 & 33 & 30 & & & 1.800 & 5.500 & 3.700 \\
\hline 3 & 56 & 30 & & & 6.000 & 11.500 & 5.500 \\
\hline 1 & 78 & 100 & & & 600 & 12.100 & 11.500 \\
\hline 3 & 56 & 30 & & & 3.900 & 15.000 & 12.100 \\
\hline 2 & 56 & 60 & & & 2.500 & 17.500 & 15.000 \\
\hline 3 & 56 & 30 & & & 1.100 & 18.600 & 17.500 \\
\hline 1 & 56 & 100 & & & 1.700 & 20.300 & 18.600 \\
\hline 3 & 56 & 30 & & & 1.700 & 22.000 & 20.300 \\
\hline
\end{tabular}




$\begin{array}{llllll}4 & 33 & 30 & 4.300 & 26.300 & 22.000\end{array}$

The general risk indicators and risk of pedestrians is shown in graph 5. From this graph we can easily identified risk index points.

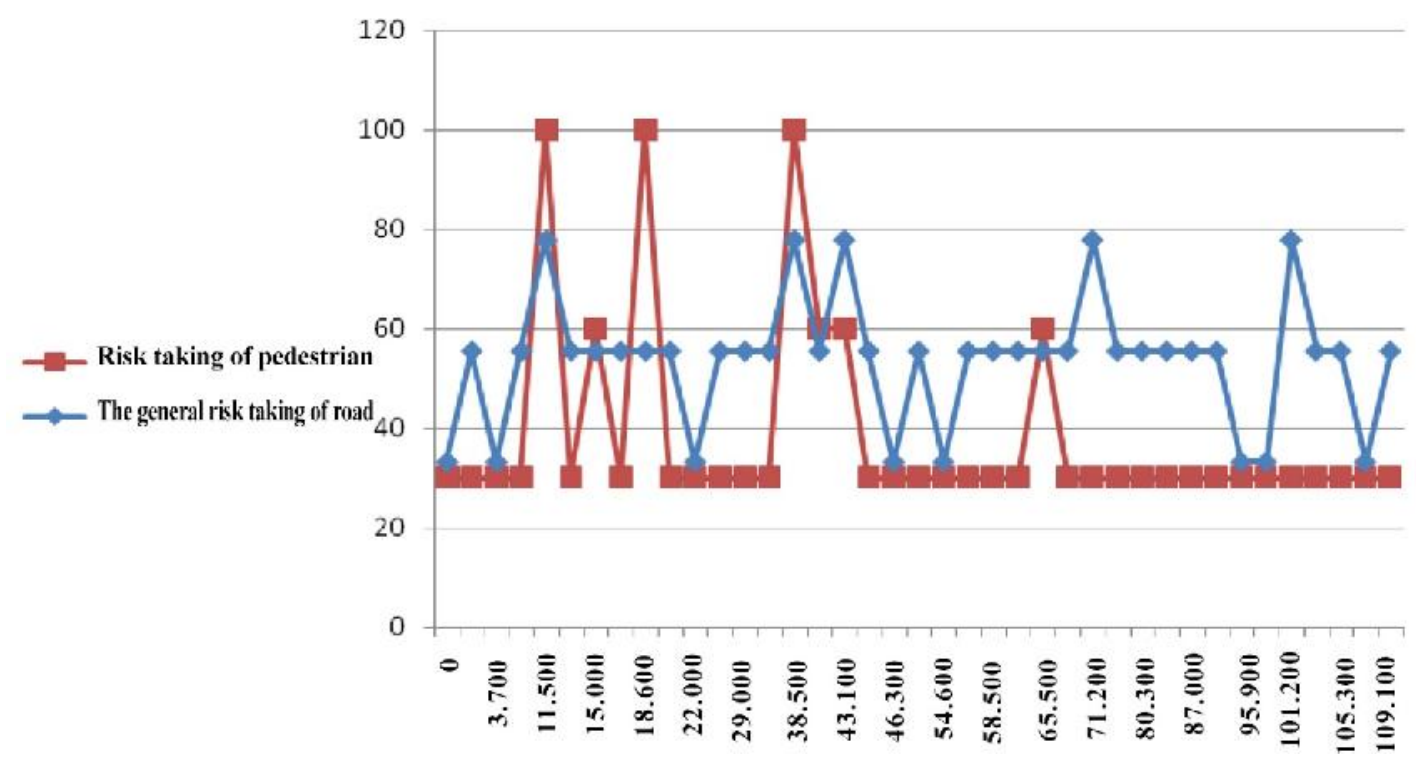

Fig.5. Risk taking indicators graph in different kilometers

\section{PROVIDE SOLUTIONS}

Due to budgetary constraints for development and improvement of roads, in many cases, improve the current status of way is done by low-cost and effective projects. The aim of such projects definition is that current status of roads vastly improve without doing demolition, reconstruction and renovation. In a way that in a short time and at low cost achieve tangible results in reducing the number and severity of accidents.

In this section proposed solutions are presented to promote road safety in the short-term and long-term time intervals. In Tables 7 to 10 some of the proposed short-term and long-term strategies are presented separately according to five groupings of risks. 
Details of short-term strategies include: low cost and efficiency in the shortest time Details of long-term strategies include: high cost, and efficiency in the longer time

Table 7. The proposed short-term and long-term strategies in marginal risk group

\begin{tabular}{|c|c|c|c|c|}
\hline \multicolumn{2}{|c|}{ Suggested solutions } & \multirow{2}{*}{\multicolumn{2}{|c|}{ Risk reason }} & \multirow[t]{2}{*}{ Risk group } \\
\hline Long term & Short term & & & \\
\hline $\begin{array}{l}\text { Alignment of } \\
\text { margin and make } \\
\text { it passable }\end{array}$ & $\begin{array}{l}\text { Protection with } \\
\text { side panel }\end{array}$ & 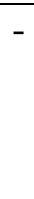 & $\begin{array}{l}\text { Failure to provide barrier-free } \\
\text { area }\end{array}$ & Margin \\
\hline $\begin{array}{l}\text { Displacement of } \\
\text { panels using } \\
\text { flexible board }\end{array}$ & $\begin{array}{l}\text { Protect the base } \\
\text { boards using a } \\
\text { side panel or } \\
\text { bumpers }\end{array}$ & & $\begin{array}{l}\text { Existence of unprotected } \\
\text { obstacles }\end{array}$ & Margin \\
\hline $\begin{array}{l}\text { Making gables } \\
\text { sloop measurable }\end{array}$ & Putting side panel & - & $\begin{array}{l}\text { Gables steep slope and } \\
\text { impassable for vehicles }\end{array}$ & Margin \\
\hline $\begin{array}{l}\text { Matching canal } \\
\text { and bridge } \\
\text { section with } \\
\text { previous sections }\end{array}$ & Putting side panel & - & Canal and bridge & Margin \\
\hline
\end{tabular}

Table 8. The proposed short-term and long-term strategies in geometric design risk group

\begin{tabular}{lllll}
\hline \multicolumn{2}{c}{ Suggested solutions } & & Risk reason & Risk group \\
\cline { 1 - 2 } Long term & Short term & & \\
\hline Geometric & use of horizontal & With a low radius & Left-handed & Geometric design \\
correction of & and vertical & and vision & horizontal arc & \\
curve and supply & warning signs & distance & & \\
the required sight & & & & \\
distance & & & & \\
\hline
\end{tabular}


G. Ghaffari et al.

\begin{tabular}{lllll}
\hline $\begin{array}{l}\text { Geometric } \\
\text { correction of }\end{array}$ & $\begin{array}{l}\text { use of horizontal } \\
\text { and vertical } \\
\text { curve and supply } \\
\text { the required sight } \\
\text { wistance }\end{array}$ & $\begin{array}{l}\text { With a low radius } \\
\text { and vision } \\
\text { distance }\end{array}$ & $\begin{array}{l}\text { Right-handed } \\
\text { horizontal arc }\end{array}$ & $\begin{array}{l}\text { Geometric design } \\
\text { Geometric }\end{array}$ \\
$\begin{array}{l}\text { use of horizontal } \\
\text { correction of }\end{array}$ & With low length & Convex vertical & Geometric design \\
$\begin{array}{l}\text { curve and supply } \\
\text { ane required sight }\end{array}$ & warning signs & & arc & \\
distance & & & & \\
\end{tabular}

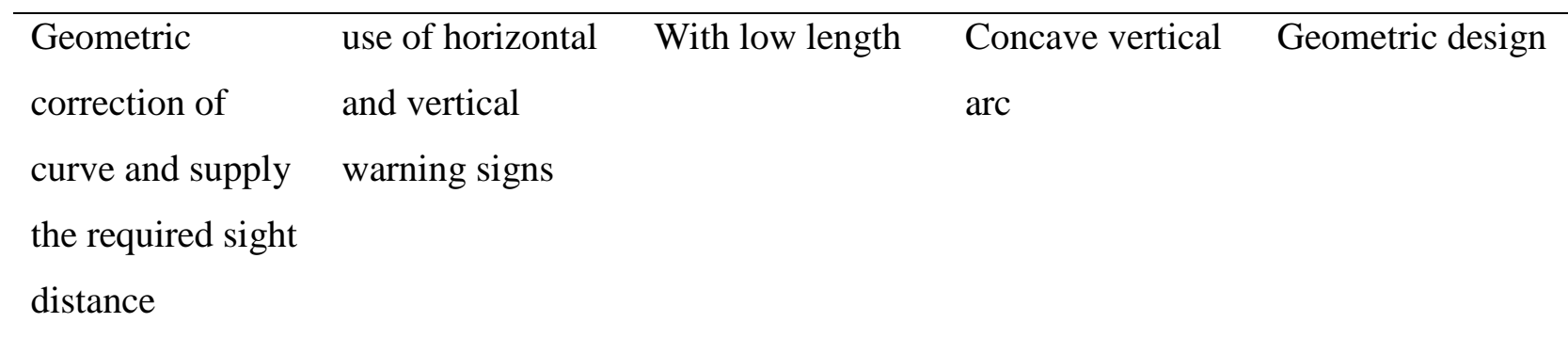

\begin{tabular}{|c|c|c|c|c|}
\hline Considering the & - & & Right level & Geometric design \\
\hline speed slow down & & deceleration line & crossings with the & \\
\hline length with the & & & possibility of turn & \\
\hline proposed & & & to left & \\
\hline
\end{tabular}

Regulations

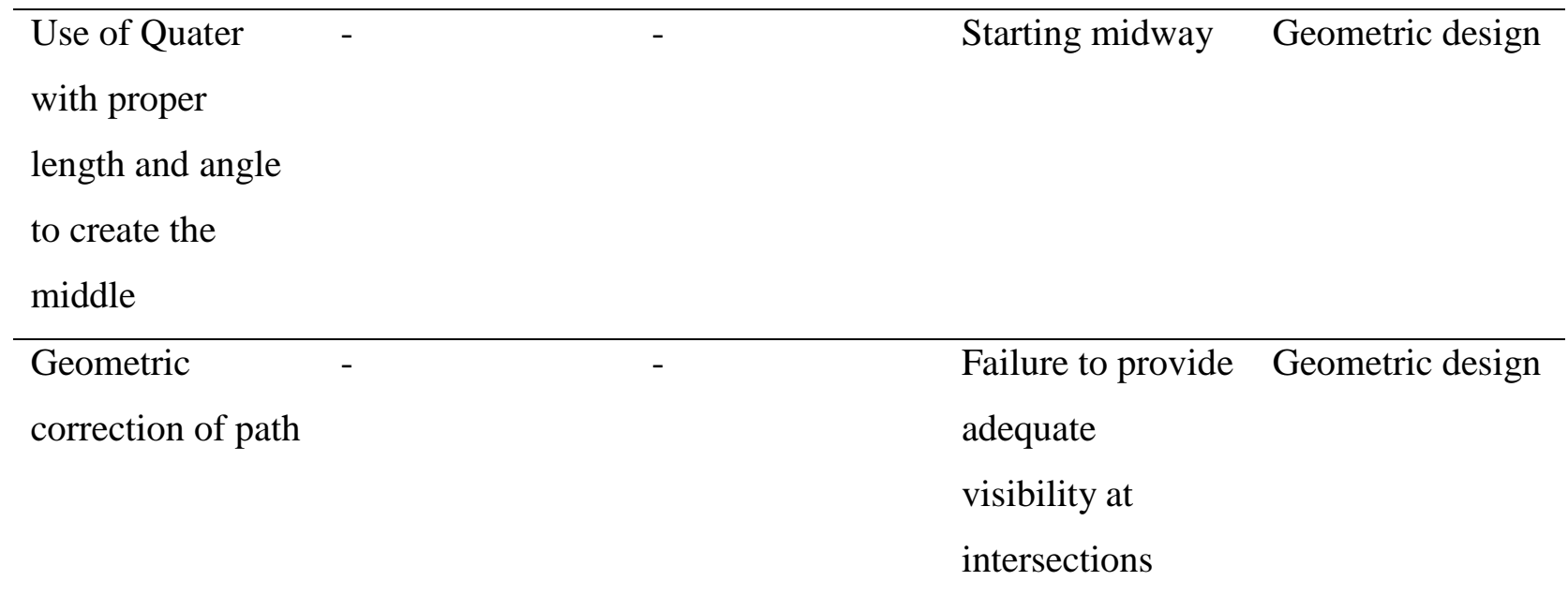


Table 9. The proposed short-term and long-term strategies in areas with different land uses risk group

\begin{tabular}{|c|c|c|c|c|}
\hline \multicolumn{2}{|c|}{ Suggested solutions } & \multirow{2}{*}{\multicolumn{2}{|c|}{ Risk reason }} & \multirow[t]{2}{*}{ Risk group } \\
\hline Long term & Short term & & & \\
\hline $\begin{array}{l}\text { Construction of } \\
\text { the ring road in } \\
\text { the vicinity of } \\
\text { residential areas }\end{array}$ & $\begin{array}{l}\text { Warning to road } \\
\text { users by means } \\
\text { of signs and } \\
\text { safety equipment }\end{array}$ & $\begin{array}{l}\text { Passing the road } \\
\text { through the area }\end{array}$ & residential areas & $\begin{array}{l}\text { Areas with } \\
\text { different land use }\end{array}$ \\
\hline $\begin{array}{l}\text { creating local } \\
\text { tardigrade band } \\
\text { and reducing } \\
\text { traffic by adding } \\
\text { it to the road } \\
\text { from controlled } \\
\text { intersection }\end{array}$ & $\begin{array}{l}\text { Restrict user } \\
\text { access to install } \\
\text { warning signs } \\
\text { and priority }\end{array}$ & $\begin{array}{l}\text { Access to road } \\
\text { without control } \\
\text { and security }\end{array}$ & residential areas & $\begin{array}{l}\text { Areas with } \\
\text { different land use }\end{array}$ \\
\hline $\begin{array}{l}\text { Remove vision } \\
\text { obstacles and } \\
\text { provide needed } \\
\text { sight distance }\end{array}$ & $\begin{array}{l}\text { To provide } \\
\text { brightness- } \\
\text { warning signs - } \\
\text { reduce traffic }\end{array}$ & - & $\begin{array}{l}\text { Failure to } \\
\text { provide adequate } \\
\text { sight distance for } \\
\text { pedestrians }\end{array}$ & $\begin{array}{l}\text { Areas with } \\
\text { different land use }\end{array}$ \\
\hline $\begin{array}{l}\text { Remove vision } \\
\text { obstacles and } \\
\text { provide needed } \\
\text { sight distance }\end{array}$ & $\begin{array}{l}\text { To provide } \\
\text { brightness- } \\
\text { warning signs - } \\
\text { reduce traffic }\end{array}$ & - & $\begin{array}{l}\text { Failure to } \\
\text { provide adequate } \\
\text { brightness for } \\
\text { pedestrians }\end{array}$ & $\begin{array}{l}\text { Areas with } \\
\text { different land use }\end{array}$ \\
\hline $\begin{array}{l}\text { Creating } \\
\text { pedestrian } \\
\text { crossings } \\
\text { without same } \\
\text { level }\end{array}$ & $\begin{array}{l}\text { Creating } \\
\text { pedestrian } \\
\text { crossings with } \\
\text { same level }\end{array}$ & - & $\begin{array}{l}\text { Low number of } \\
\text { pedestrian } \\
\text { walkways along } \\
\text { the road }\end{array}$ & $\begin{array}{l}\text { Areas with } \\
\text { different land use }\end{array}$ \\
\hline
\end{tabular}




\begin{tabular}{llll}
\hline & & & \\
\hline creating local & Restrict user & - & Access to road \\
tardigrade band & access to install & Areas with \\
and reducing & warning signs & and security & \\
traffic by adding & and priority & & \\
it to the road & & \\
from controlled & & \\
intersection & & \\
\hline
\end{tabular}

Table 10. The proposed short-term and long-term strategies in safety equipment risk group

\begin{tabular}{|c|c|c|c|c|}
\hline \multicolumn{2}{|c|}{ Suggested solutions } & \multirow[b]{2}{*}{ reason } & \multirow[t]{2}{*}{ Risk } & \multirow[t]{2}{*}{ Risk group } \\
\hline Long term & Short term & & & \\
\hline- & $\begin{array}{l}\text { Install required panel in the } \\
\text { proper position with } \\
\text { dimensions specified in } \\
\text { bylaws and standard side } \\
\text { distance from paving edge }\end{array}$ & $\begin{array}{l}\text { Left-handed } \\
\text { horizontal } \\
\text { arc }\end{array}$ & $\begin{array}{l}\text { Lack of } \\
\text { signage }\end{array}$ & $\begin{array}{l}\text { Safety } \\
\text { equipment }\end{array}$ \\
\hline- & $\begin{array}{l}\text { Install required panel in the } \\
\text { proper position with } \\
\text { dimensions specified in } \\
\text { bylaws and standard side } \\
\text { distance from paving edge }\end{array}$ & $\begin{array}{l}\text { Right- } \\
\text { handed } \\
\text { horizontal } \\
\text { arc }\end{array}$ & $\begin{array}{l}\text { Lack of } \\
\text { signage }\end{array}$ & $\begin{array}{l}\text { Safety } \\
\text { equipment }\end{array}$ \\
\hline- & $\begin{array}{l}\text { Install required panel in the } \\
\text { proper position with } \\
\text { dimensions specified in } \\
\text { bylaws and standard side } \\
\text { distance from paving edge }\end{array}$ & $\begin{array}{l}\text { right } \\
\text { Intersection } \\
\text { exit }\end{array}$ & $\begin{array}{l}\text { Lack of } \\
\text { signage }\end{array}$ & $\begin{array}{l}\text { Safety } \\
\text { equipment }\end{array}$ \\
\hline
\end{tabular}




\begin{tabular}{lllll}
\hline- & $\begin{array}{l}\text { Moving the position of } \\
\text { lighting and place it in a } \\
\text { place with good visibility }\end{array}$ & $\begin{array}{l}\text { The } \\
\text { radiation } \\
\text { angle of the } \\
\text { sun }\end{array}$ & $\begin{array}{l}\text { Installation } \\
\text { of traffic } \\
\text { lights }\end{array}$ & $\begin{array}{l}\text { Safety } \\
\text { equipment }\end{array}$ \\
& Warning to drivers and stop & - & Lack of & Safety \\
Installation of & ban & & ventilation & equipment \\
ventilation & & & system & \\
system inside the & & & inside the & \\
tunnel & & & tunnel & \\
& & & &
\end{tabular}

Also in figures 6 to 8 examples of low-cost and quick measures have been displayed for promotion of the status of the equipment and safety systems and horizontally and vertically signs.

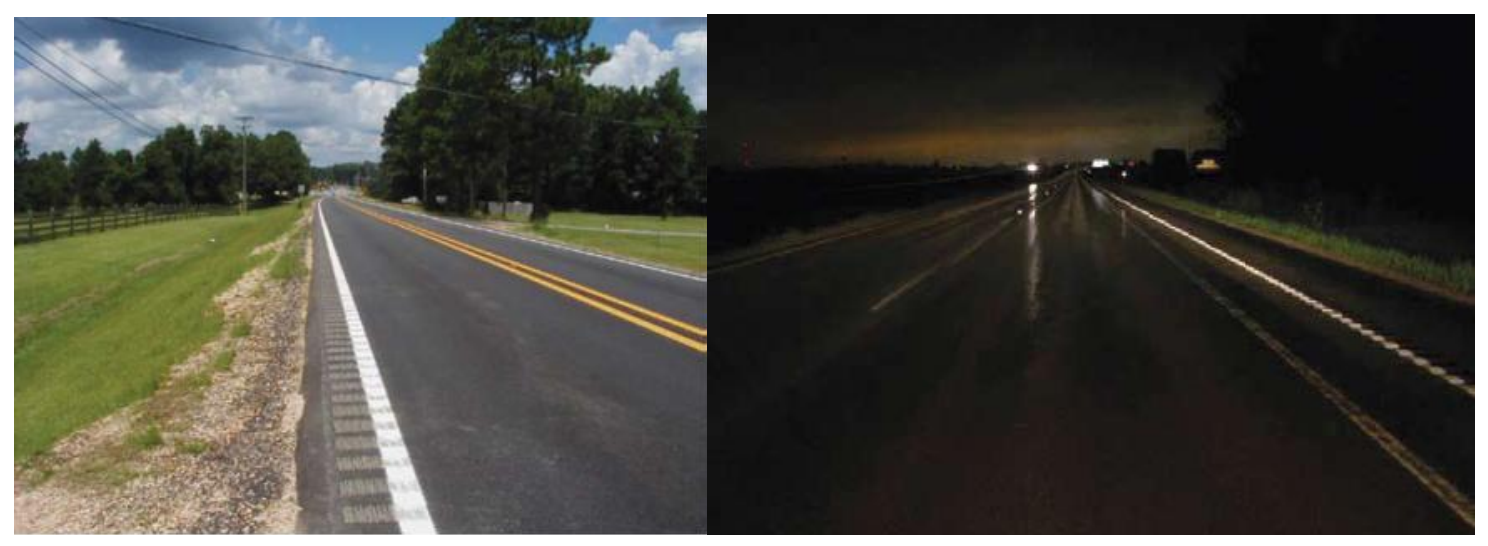

Fig.6. Vibration groove of road margin

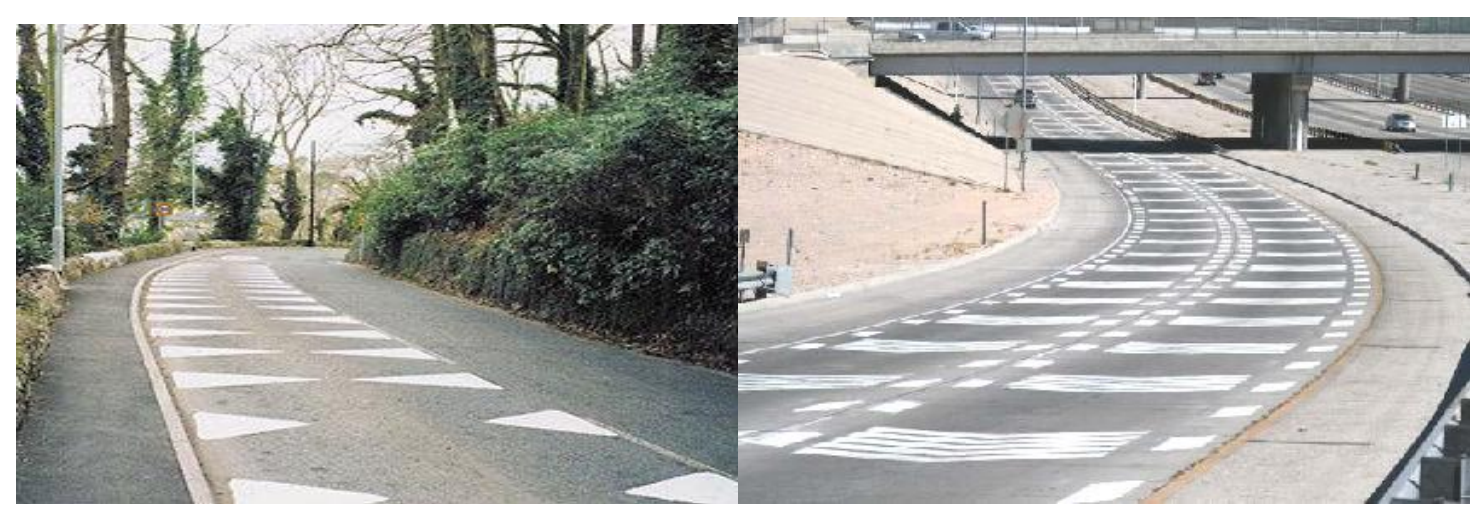

Fig.7. Examples of bar lines in road margin to reduce speed 

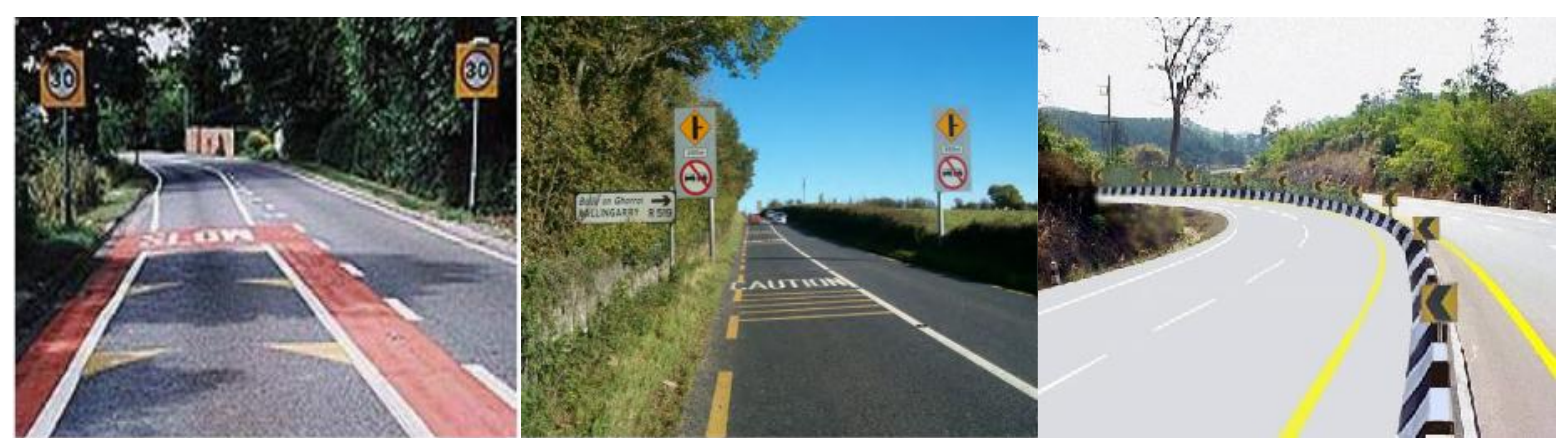

Fig.8. The combination of vertical and horizontal signs to reduce traffic

\section{CONCLUSION}

Improving road safety requires constant integrated and systematic efforts in various fields, such as safety management and coordination, proper system of collection, processing and presentation of data traffic, designing and building safe roads, improvement and elimination of accident-prone places, advertising and effective education of safety, vehicle safety standards, regulations and traffic rules and apply them, rescue and medical emergency, that determining the status of each one of them has various parameters. According to the recommendations by international bodies, determining the major indices that their obtaining is an essential condition for achieving improved road safety situation is necessary. The results of this study have shown that in addition to factors affecting the geometric design of roads, physical agents and equipment and signs on the road, as well as indicators related to their maintenance also have an important role in ensuring road safety. The total weight of roads' horizontal signs impact (striping and text lines and speed hump) were equal 0.306 and the total weight of road vertical signs (regulatory and warning signs, traffic lights) were equals 0.181 . This shows the importance and the effect of horizontal systems on roads more than marginal vertical signs. That has up to 45 percent importance on road immune function. According to prioritize taken in this research, it was found that $56 \%$ have $4^{\text {th }}$ priority in safety improvement, $21 \%$ have the third priority and $15 \%$ have first priority, $8 \%$ have second improvement Priority that are shown in Table 11. 
Table 11. Percentage of sections priority to improve safety in case study

\begin{tabular}{|c|c|c|}
\hline Priority & $\begin{array}{c}\text { Number of } \\
\text { number }\end{array}$ & priorities \\
\cline { 2 - 3 } Priority 1 & 6 \\
\cline { 2 - 3 } Priority 2 & 3 \\
\hline Priority 3 & 8 \\
\hline Priority 4 & 22 & \\
\hline
\end{tabular}

\section{REFERENCES}

[1] World Health Organization, "Road Safety not Accident", A Brochure for World Health Day, 7 April 2004.

[2] Ghaffari, Gh. Zoghi, h. The effect of using road safety supplying equipment and systems and determine their role in suburban road safety performance, 1394, A Thesis of Islamic Azad University, Ayatollah Amoli Science and Research branch.

[3] Ministry of Transportation, the Supreme Council of reform, determine the contribution of factors contributing to the occurrence and severity of road accidents, based on their abundance in 1381.

[4] La Torre, F., et al., Improving Roadside Design to Forgive Human Errors. Procedia-Social and Behavioral Sciences, 2012. 53: p. 235-244.

[5] Thomson, R., D06: European Best Practice for Roadside Design: Guidelines for Roadside Infrastructure on New and Existing Roads. 2006, Deliverable.

[6] Manual on Uniform Traffic Control Devices for Street and Highways, U.S. Department of Transportation, Federal Highway Administration, 2003 Edition. 
[7] Asgharpour, MJ. "Multiple Criteria Decision Making", Tehran University Press, 191-296, Fourth Edition, 1385.

[8] Ghodsi Pour, H. "Analytic Hierarchy Process (AHP)", Amir Kabir University, Fourth Edition: 1384.

\section{How to cite this article:}

Ghaffari $\mathrm{G}$ and Zoghi $\mathrm{H}$. The effect of using road safety equipment and systems and determine their role on the suburban roads' safety performance. J. Fundam. Appl. Sci., 2016, 8(3S), 631653. 